\title{
Zoning of the territory of Western Polissya of Ukraine for anthropogenic loading and ecological status of small river basins
}

Yatsyk A. ${ }^{1}$, Pasheniuk I. ${ }^{2}$, Gopchak I. ${ }^{3}$, Basiuk T. ${ }^{4}$

1, 2Ukrainian research institute of water management and ecological problems, Engineering lane, 48, Kyiv, 01010, Ukraine, ${ }^{3}$ National university of water and environmental engineering, Soborna Str., 11, Rivne, 33028, Ukraine, 4 International university of economics and humanities, Academician Stepan Demianchuk Str., 4,

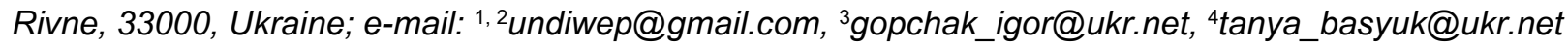

The purpose. To execute zoning of territory of Western Polissia of Ukraine on anthropogenic load and to evaluate ecological state of basins of small rivers. Methods. Study was conducted according to regular observation within the limits of basins of the probed rivers with the use of system model of hierarchical structure «Basin of small river». The given model realized grading basins of small rivers on extent of anthropogenic loads and allowed tracking state of water-collecting area on various indexes in a slit of separate subsystems (radioactive impurity of territory, use of lands, use of river flow, quality of water). Results. At account of extent of anthropogenic load on basin of small rivers they evaluated quantitative and quality indicators of separate subsystems. It was established that on aggregate of all criteria the ecological state of basins in $33 \%$ of rivers was characterized as «changes negligible», 25 - state «satisfactory», in $42 \%$ - state «bad» and «very bad». General ecological state of basins of small rivers of Western Polissia was unsatisfactory. By results of water-ecological zoning of territory of probes they offered some nature protection measures. In particular, in all basins of rivers of Western Polissia first of all it is necessary to increase amount of forests, to diminish the areas of agricultural lands and index ploughing. Conclusions. With the purpose of martempering and restoring of the disturbed natural state of basins of small rivers of Western Polissia of Ukraine it is necessary to hold water-ecological zoning of their territories. That will promote density of force of all objects of control and managing for development and implementation of general basin and territorial nature protection measures.

Key words: river, surface waters, water-collecting area, quality of water, ecological evaluation.

https://doi.org/10.31073/agrovisnyk201901-10

Introduction (problem). The small river basin is an indicator of the state of the environment, which is due to the level of anthropogenic load on the components of its landscape complexes. Determination of the level of anthropogenic impact on small river catchment bases is based on the ecosystem or basin approach, which consists in a comprehensive assessment of the use of land and water resources, structure and contamination of landscapes. Modern intensive use of land and water resources in river ecosystems has led to a disturbance of the ecological balance and the emergence of a number of water management and environmental problems. Therefore, the study of anthropogenic transformation in the basins of small rivers is of particular relevance for determining the dependence of changes on the intensity of anthropogenic loads [1-3].

Analysis of recent research and publications of the subject. The study of the assessment of the status of river basins was undertaken by such scientists as: L. Byshovets, E. Bogatov, V. Zhukinsky, A. Kirilyuk, A. Ogievsky, V. Romanenko, V. Romanenko, V. Khilchevsky, A. Yatsyk, and others.

The purpose of the research - to perform zoning of the territory of Western Polissya of Ukraine for anthropogenic load and to assess the ecological status of the basins of small rivers.

The object of research is the choice of 24 rivers, the basins of which are located within the Western Polissya.

Materials and methods. In calculating anthropogenic load and assessing the ecological state of small rivers of Western Polissya of Ukraine and their basins, the Methodology for Calculation of Anthropogenic Load and Classification of the Ecological Condition of the Basins of Small Rivers of Ukraine was used [3]. The basis of the methodology is the system logic-mathematical model of the hierarchical structure "Small River Basin", 
which carries out the classification of small river basins by the degree of anthropogenic loads acting on them. This model is based on the ecosystem principle, and allows us to trace the status of the river basin according to various indicators within the individual subsystems (radioactive contamination of the territory, use of land, use of river runoff, water quality), as well as the river basin as a whole. This allows us to assess not only the general state of the river basin, but also to formulate an understanding of how changes in individual indicators of subsystems affect the state of the entire system of the basin, which is very important for forming areas of environmental activity in the basins of specific rivers.

An important feature of the proposed system model is that the evaluation of system states, subsystems in this model is performed in parallel in two directions - quantitative and qualitative: the qualitative state of the subsystems performance is evaluated, in which the quantitative measure is determined on the set of states of individual subsystems, and on the basis of quantitative measures of individual subsystems is determined by the quantitative measure of the whole system. As a result, the assessment of the state of all four subsystems determines a general assessment of the state of the entire pool system. According to the quantitative measure of the qualitative state of the whole system, the following states of the river basin are defined: "good", "minor changes", "satisfactory", "bad", "very bad", "catastrophic". One or another assessment of the state of the pool reflects the degree of anthropogenic load and the ecosystem's response to this load [4-6].

The source materials for the calculation of anthropogenic loading were statistical and cartographic data of the ecological status and use of land and water resources in the basins of the small rivers of Western Polissya.

Research results. Environmental and ecological zoning involves assessing the status of river basins for the integrated use of water resources, which takes into account the natural conditions for the formation of river flow in the region. After all, it is precisely in conjunction with other components of the environment environmentally adapted by water factor development of the economic potential of the regions is one of the main areas of organization of a balanced water supply and water use system. At the same time, in this regionalization, it is necessary to take into account the level of radioactive contamination of the catchment area, the magnitude of the anthropogenic load on the river basins and the conditions for using the river runoff in the economy [4-9].

During the last decades, the basins of small rivers of Western Polissya of Ukraine have undergone particularly significant changes. Changes in the ecological status of river basins and the conditions for the formation of surface water quality of small Polissya rivers occurred due to the increasing influence of anthropogenic loading on their basins, as well as the lack of spatial planning of the boundaries of basin development [10].

The calculation of anthropogenic load and assessment of its impact on the ecological systems of the Western Polissya rivers are carried out on the basis of the classification (assessment) of the state of the main natural systems (subsystems) of land and water resources, the quality of water by chemical, toxicological, bacteriological and radiation pollution, and the quality of water and its use are defining [4-6]. The results of the study are presented in the table and are shown in the figure.

According to the results of the study, there is not a single small river that would have a "good" ecological status. $33 \%$ of the rivers are "minor changes", $25 \%$ are "satisfactory", and $42 \%$ are "bad" and "very bad". The status of the basins of the Slonivka, Lipa, Chernoguzhka, Ustya and Khomor rivers is estimated as "very poor".

Based on the data obtained, it can be argued that the overall ecological status of the basins of the small rivers of Western Polissya of Ukraine is generally unsatisfactory.

Taking into account the results of the estimation of anthropogenic loading and ecological status of the basins of the Western Polissya rivers of Ukraine, the water management and ecological zoning of the territory was carried out. It allows us to show not only changes in the natural state of rivers under the influence of anthropogenic loading, but also makes it possible to identify the basins (rivers) with the greatest violations from the standpoint of ecology, which require first-priority investments for their recovery. 
Table Assessment of anthropogenic loading and ecological state of the basins small rivers of Western Polissya Ukraine

\begin{tabular}{|c|c|c|c|}
\hline \multirow{2}{*}{ № } & \multirow{2}{*}{ River } & \multicolumn{2}{|c|}{ General condition of the basin } \\
\hline & & quantitative assessment & qualitative evaluation \\
\hline 1 & Vyzhivka & 0,43 & satisfactory \\
\hline 2 & Turia & 0,40 & satisfactory \\
\hline 3 & Tsir & 1,03 & changes are minor \\
\hline 4 & Stohid & 0.70 & changes are minor \\
\hline 5 & Veselukha & 1,21 & changes are minor \\
\hline 6 & Radostavka & $-0,15$ & satisfactory \\
\hline 7 & Slonivka & $-2,36$ & very bad \\
\hline 8 & Lipa & $-2,68$ & very bad \\
\hline 9 & Ikva & 0,02 & satisfactory \\
\hline 10 & Chernogurzka & $-2,97$ & very bad \\
\hline 11 & Konopelka & 0,10 & satisfactory \\
\hline 12 & Kormin & 0,55 & changes are minor \\
\hline 13 & Stubla & 1,17 & changes are minor \\
\hline 14 & Polkva & $-1,14$ & bad \\
\hline 15 & Vilia & 0,52 & changes are minor \\
\hline 16 & Ustya & $-2,97$ & very bad \\
\hline 17 & Zamchysko & $-1,88$ & bad \\
\hline 18 & Vyrka & 0,84 & changes are minor \\
\hline 19 & Khomora & -2.27 & very bad \\
\hline 20 & Tnya & $-1,04$ & bad \\
\hline 21 & Smolka & $-0,08$ & satisfactory \\
\hline 22 & Cerem & $-1,18$ & bad \\
\hline 23 & Korchyk & $-0,59$ & bad \\
\hline 24 & L'va & 0,61 & changes are minor \\
\hline
\end{tabular}




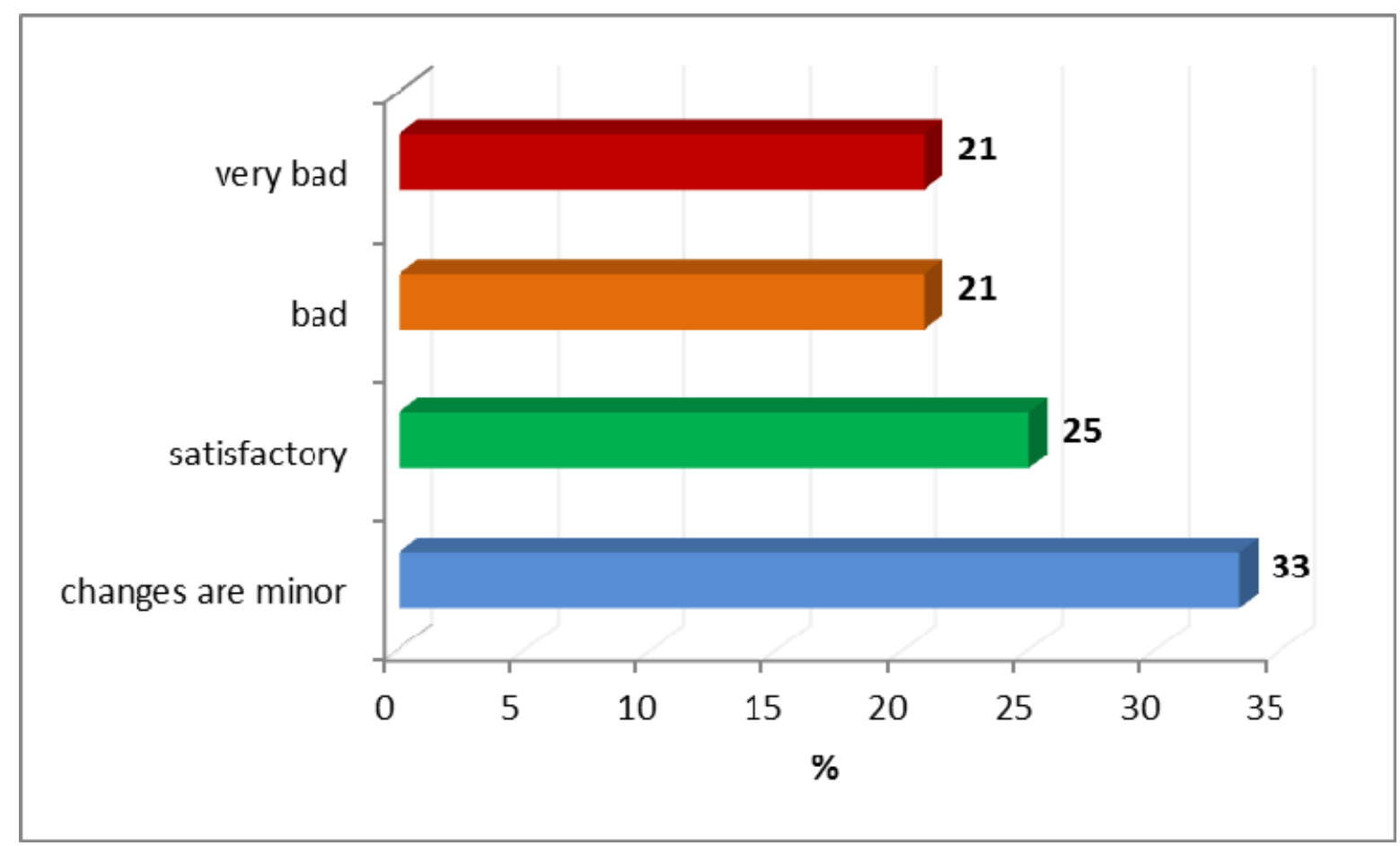

Fig. Ecological condition of the basins of small rivers of Western Polissya of Ukraine, \%

In particular, calculations have shown that in all basins of the Western Polissya rivers it is necessary to increase the forest cover, reduce the area of agricultural land and the index of plow. Of course, this will not return the past natural state of the territory and the rivers, but will help to establish lost functional links, as well as promote the reproduction at water inlets, if not natural, then natural and human-made environment of acceptable quality.

Despite the complexity of the issue of rationing the anthropogenic load on river basins, using the logicmathematical model "Small River Basin", it is possible with a gradual approach to set the values of load for each river that will not lead to the loss of self-cleaning capacity of its ecosystems.

\section{Conclusions}

Thus, despite the complexity of the issue of rationing anthropogenic loading on river basins, using the logic-mathematical model "Small River Basin", one can gradually approach the values of load for each river that will not lead to the loss of self-cleaning ability of its ecosystems. And conducting water management and ecological zoning in the basins of the small rivers of Western Polessye Ukraine will facilitate the concentration of efforts of all objects of management and management for the development and implementation of general and territorial measures to improve and restore the impaired natural state of river basins and ensure environmentally safe living conditions and conservation river ecological systems.

\section{Bibliography}

1. Yatsyk A.V. (2004) Vodogospodars'ka ekologiya [Water management ecology]Kiev: Heneza. $480 \mathrm{~s}$ [in Ukrainian]

2. Yatsyk A.V., Levyc'ka S.O., Pashenyuk I. A. (2007) Antropogenne navantazhennya na vodni ekosy`stemy` ta osnovni pry'ncy'py` ekologichnogo normuvannya [Anthropogenic pressure on aquatic ecosystems and basic principles of ecological regulation] Rivne : NUVHP, S. 108-119 [in Ukrainian]

3. Yatsyk A.V. (1997). Ekolohycheskye osnovy ratsyonalnoho vodopolzovanyia [Ecological basis of rational water use]. Kiev : Heneza. 640 s. [In Russian].

4. Yatsyk A.V., By`shovec L.B., Bogatov E.O. (2007) Metodyka rozraxunku antropogennogo navantazhennya i klasyfikaciyi ekologichnogo stanu basejniv malyx richok Ukrayiny [Method of calculation of anthropogenic loading and classification of ecological status of basins of small rivers of Ukraine] Kiev? $67 \mathrm{~s}$. [in Ukrainian].

5. Yatsyk A., Pasheniuk I., Hopchak I., Basiuk T. (2017). Vodogospodars`ko-ekologichne rajonuvannya yak osnova zberezhennya i vidnovlennya vodnyx resursiv [Water management and ecological zoning as the basis 
for the preservation and restoration of water resources] Zbirka dopovidej Mizhnarodnogo Kongresu "ETEVK2017". Ky'yiv, TOV "PRAJM-PRINT". - S. 167-171 [in Ukrainian].

6. S. Levyc'ka, I. Pashenyuk (2007) Konceptual'ni ta metodologichni zasady ekologo-vodogospodars'kogo rajonuvannya [Conceptual and methodological principles of ecological and water-zoning zoning] Vodne gospodarstvo Ukrayiny № 4. - S. 37-43. [in Ukrainian].

7. Shevchuk V. Ya. (2001) Pro Koncepciyu perexodu Ukrayiny do stalogo rozvytku [About the Concept of Ukraine's Transition to Sustainable Development] Problemy stalogo rozvytku Ukrayiny: statti Kyiv, S. 42-51. [in Ukrainian]

8. Xvesyk M. A. (2008) Strategichni imperatyvy racional'nogo pryrodokorystuvannya v konteksti social'noekonomichnogo pidnesennya Ukrayiny [Strategic imperatives of rational nature management in the context of socio-economic uplift of Ukraine] Monografiya, Donecz"k : TOV "Yugo-Vostok Ltd", $496 \mathrm{~s}$. [in Ukrainian]

9. Yatsyk A.V., Gryshchenko Yu. M, Volkova L. A.,. Pashenyuk I. A (2007) Vodni resursy: vykorystannya, oxorona, vidtvorennya, upravlinnya: [Water resources: use, protection, reproduction, management] - Kyiv: Geneza,. - 360 s. [in Ukrainian]

10. Klymenko O., Statnyk I. (2012). Metodolohiia pokrashchennia ekolohichnoho stanu richok Zakhidnoho Polissia (na prykladi r. Horyn) : monohrafiia [Methodology for improving the ecological status of the rivers of Western Polissya (for example, the Gorin River): monograph]. Rivne : NUVHP. 206 s. [in Ukrainian]. 